\title{
Social Effects of Crude Oil Production Activities in Egbema, Imo State, Nigeria
}

\author{
I. E. Osumgborogwu ${ }^{1 *}$, F. C. Okoro ${ }^{1}$ and I. J. Oduaro ${ }^{1}$ \\ ${ }^{1}$ Department of Geography and Environmental Management, Imo State University, P.M.B. 2000, \\ Owerri, Nigeria.
}

Authors' contributions

This work was carried out in collaboration between all authors. Author IEO designed the study, performed the statistical analysis, wrote the protocol and wrote the first draft of the manuscript. Authors FCO and IJO managed the analyses of the study. Author IJO managed the literature searches. All authors read and approved the final manuscript.

Article Information

DOI: 10.9734/ARJASS/2017/33164

Editor(s):

(1) Shiro Horiuchi, Faculty of International Tourism, Hannan University, Japan.

Reviewers:

(1) Natt Makul, Phanakhon Rajabhat University, Thailand. (2) Diana Bílková, University of Economics, Prague, Czech Republic. Complete Peer review History: http://www.sciencedomain.org/review-history/19223

Short Research Article

Received $1^{\text {st }}$ April 2017

Accepted $24^{\text {th }}$ May 2017

Published 27 $7^{\text {th }}$ May 2017

\section{ABSTRACT}

Literature abounds on the economic and environmental effects of crude oil production activities in the oil producing communities of Nigeria. Some of these effects include reduction in economic and agricultural activities due to oil spillage and gas flaring as well as health challenges. While efforts are being made to curtail some of these problems, sufficient attention has not been paid in published literature to the social dimension of crude oil production in Nigeria. This study thus sets out to assess social effects of crude oil exploration and extraction activities in some selected communities in Egbema of Imo State. To achieve this, 150 copies of well-structured questionnaire were distributed to residents of the study area. Of this number, 141 copies were correctly filled and returned, thus, representing 94 percent of respondents. Ten oral interviews were also conducted with identified heads of households. The results as presented in Tables 1 and 2 show that social activities in the community have not been affected by crude oil production. However, some hostile behaviours such as youth restiveness as a result of demand for compensation/payment from oil companies operating in the study area were observed. It is therefore recommended that further research be carried out to assess security effects of crude oil production. This paper thus 
concludes that effects of crude oil production activities are obvious in the environmental, agricultural and economic sectors of lives of the affected population, but same may not be said of the social components of their lives.

Keywords: Crude oil production; social effects; oil producing communities; Egbema.

\section{INTRODUCTION}

Nigeria is blessed with the abundance of minerals in both solid, liquid and gaseous forms in different parts of the country. Of these natural minerals, petroleum products account for over 85 percent of the Nation's Gross Domestic Product (GDP); over 95 percent of the National budget; and over 80 percent of the national wealth [1]. It is sad, however, to observe that damage to the environment is usually seen as an unavoidable consequence of maintaining national development [2]. This statement holds true for many oil producing communities in Nigeria whose livelihoods are presumed to be negatively affected by ecologically unfriendly exploitation of oil. Crude oil production has adversely affected the lives of inhabitants of oil producing communities, for example, fishing and farming activities have been greatly reduced as a result of pollution and gas flaring, some health hazards are equally associated with these ecologically hostile behaviours [1-4].

The environment is made up not only of the physical or built components, but also, of the social elements. Efforts have been made to assess effects of crude oil production on the physical environment, it is also possible that activities of oil companies affect social lives of people within the affected population.

\subsection{Statement of the Problem}

It is trite to state that the petroleum industry in Nigeria is the largest industry [5]. It generates over 90 percent of the nation's foreign exchange earnings and over 80 percent of government annual revenue [6]. Despite these, adverse effects of oil production in Nigeria are obvious in environmental, agricultural and health sectors. Published reports show that some activities associated with crude oil production can lead to environmental degradation, malnutrition in children and loss of livelihood [3,7]. However, little is known in published literature regarding effects of crude oil production on the social lives of oil producing communities. Is it possible that crude oil production affects the social lives of people in the affected community? This study intends to fill this gap by assessing the social effects of oil production in Egbema Community of Imo State.

The aim of this work is to evaluate social effects of crude oil production in oil producing communities. To achieve this aim, the following specific objectives were achieved; identification of crude oil production activities in the study area, identification of types of social activities in the community, and assessment of effects of crude oil production on the social lives of the community. It was hypothesised in this study that crude oil production has no significant effect on the social activities of people in oil producing communities.

\subsection{Study Area}

Egbema is one of the districts of Ohaji/Egbema Local Government Area (LGA) in Imo State, Fig. 1. It lies between latitudes $4.3623^{\circ} \mathrm{N}$ and $5^{\circ} 11^{\prime} 32^{\prime \prime} \mathrm{N}$ and longitudes 624 $0^{\circ} \mathrm{E}$ and 720 $59^{\prime \prime} \mathrm{N}$. Egbema is located in the southwestern part of Imo State and shares common boundaries with Ohaji District in the East, Oguta in the North and Ogba/Egbema/Ndoni LGA of Rivers State in the south-west. It is one of the oil producing regions of Imo State. The study area has sixteen communities, three of which are in Rivers State and thirteen are in Imo State. The communities found in Imo State include; Mmahu (headquarters of the LGA), Abacheke, Opuoma, Umuorji, Obokofia, Obiakpu, Mgbara, Ekugba, Etekwuru, Abiezi, Obeakpu, Ukwugba, and Oforola. Egbema displays similar geological formation of the delta areas. It lies within the fresh water alluvial zone and the Sombrero-Warri Deltaic plain of the Niger Delta, underlain by the Coastal Plain Sands of the Benin formation [8].

The people of Egbema have rich cultural heritages which reflect their high regard for tradition. These cultural heritages include; Ichiozo, Igwa-ji, Igba-mgba, Iwu-azhi, Isu-uzo, Igbaowu, and Idu-miri. The study area host's some oil companies such as Nigerian Agip Oil Company (NAOC), Nigeria Petroleum Development Company (NPDC) and Addax Oil Company. Egbema is one of the agricultural zones of Imo State, hence, agriculture is the mainstay of the 


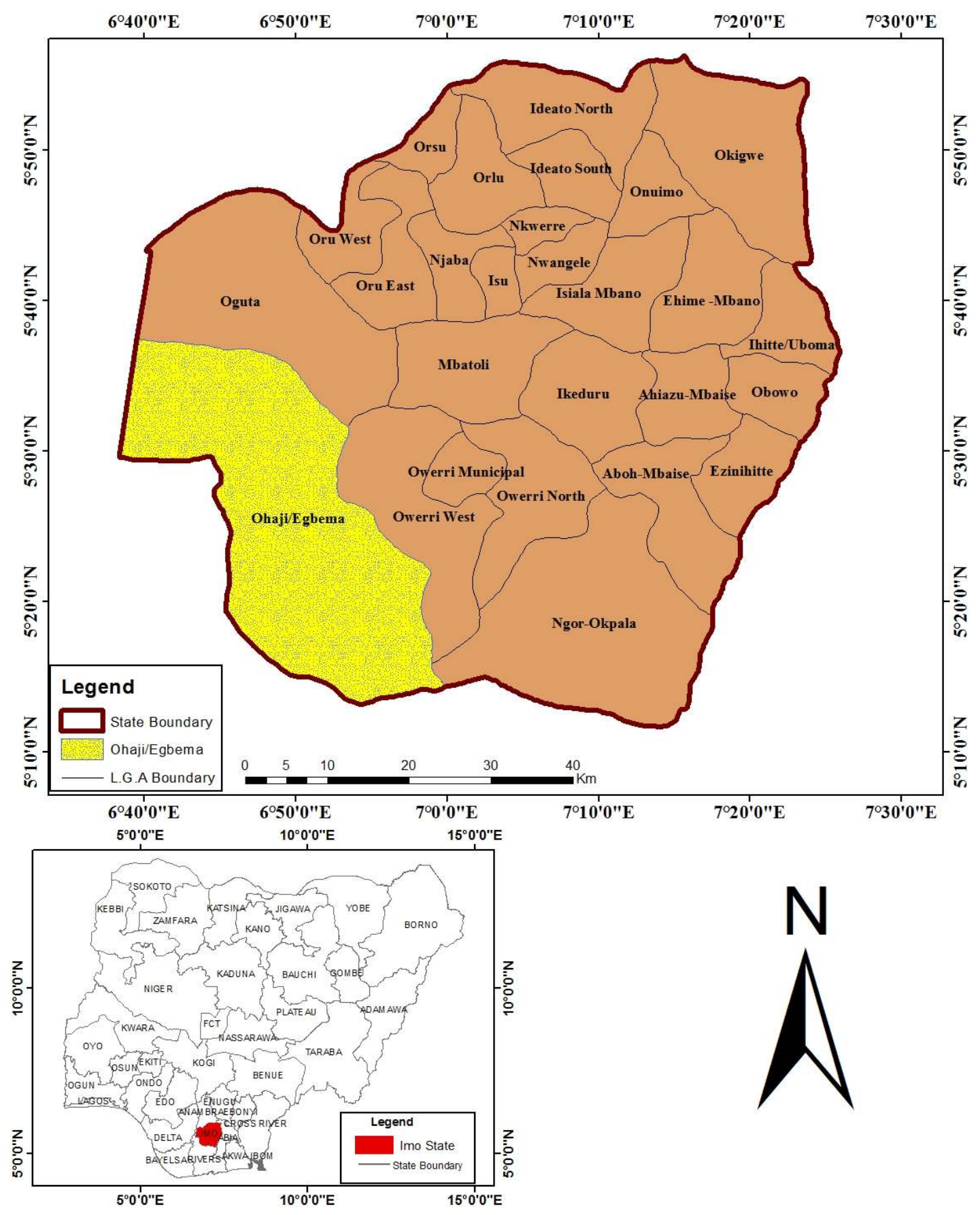

Fig. 1. Study area

people. Farming, fishing, palm oil processing, hunting and animal husbandry are practised in the community.

\section{LITERATURE REVIEW}

Studies in Nigeria show that the petroleum industry occupies a strategic position in the economic development of Nigeria [9]. For example, between 2000 and 2009, the total oil revenue generated into the Federation Account amounted to N34.2 trillion while non-oil was N7.3 trillion, representing 82.4 percent and 17.6 percent respectively [5]. 
Despite this, studies have documented adverse effects of crude oil extraction in Nigeria. For instance [6] examined the effects of oil spillage on cassava farm land, yield and land productivity in the Niger Delta. Their results indicated that significant effects of oil spillage on cassava production perceived by the farmers included crop failure, poor yield, rotting tubers, and stunted crop growth with mean scores of 4.80 , $4.78,4.75$ and 4.75 respectively. Other effects include increased soil temperature and toxicity (mean: 4.73), reduction of soil fertility (mean: 4.70), degradation of farm land (mean: 4.70) and low land productivity (mean: 4.70). They concluded that constant maintenance of oil pipelines and tankers in order to prevent corrosion and checkmating activities of saboteurs which often destroy oil pipelines will reduce the occurrence of oil spillage, hence increasing cassava production in the Niger Delta region.

Study conducted by [7] suggests that unplanned exploitation of mineral resource like crude oil has led to gas flaring and this produces harmful environmental heat, which scorches surrounding soil and makes vegetation and farmland look parched. [10] adopted the twin tools of GIS and Remote Sensing in an assessment of the physical impact of oil spillage in Jesse Town of Delta State. They found that oil spillage was increasing unabated in the study area. With this increase in the occurrence of oil spillage comes a commensurate increase in the degradation of agricultural lands thereby turning hitherto productive areas into waste lands.

[11] documented some of the environmental problems associated with oil exploration and production in the Niger Delta to include oil spills, gas flaring and venting, discharges of petroleumderived chemical wastes, contamination of controlled water sources, contamination of soil and sediments, the destruction of the farmland and the marine environment. They went further to state that some 45.8 billion kilowatts of heat are discharged into the atmosphere of the Niger Delta from combustion of 1.8 billion cubic feet of gas every day. This is a major contributing factor to the global warming crises.

Researching on the effects of air pollution arising from associated gas flaring on the economic life of the people of oil producing communities in Nigeria, [12] found that the ozone concentrations for four fields studied were relatively high. Farmers in their study area reported occurrence of mottling (discolouration) in the leaves of crops such as cassava, yams, vegetables, okro and other food crops within a few days of cultivation. Eventually, these discoloured plants die thereby costing farmers huge losses.

[3] documented some health hazards accruing from oil spillage. They found that oil spills could lead to a 60 percent reduction in household food security and were capable of reducing the ascorbic acid content of vegetables by as much as 36 percent and the crude protein content of cassava by 40 percent. These they observed could result in a 24 percent increase in the prevalence of childhood malnutrition. The authors concluded that oil spills in the Niger delta region have acute and long-term effects on human health. [13] also documented some health challenges faced by people of oil-bearing communities to include high level of emotional distress, risk perception of dreaded hazards (catastrophic fears of pipeline explosions and oil spill fire), disease symptoms and environmental distress (worry, annoyance and intolerance). The authors concluded by highlighting the need for some intervention to ameliorate the psychological distress associated with living under such environmental adversity.

Commenting on the economic relationship between crude oil production and rate of poverty in the oil producing Niger Delta, [1] highlighted the devastation of the Niger Delta environment as a result of several decades of oil production and the profound changes that had adverse effects on the local livelihoods and social wellbeing. They reported that the Niger Delta environment has suffered degradation as a result of oil and gas exploration leading to air pollution, water pollution and land degradation from oil spillage and gas flaring. They concluded that a number of social vices experienced in the region are direct effects from the economic implications introduced into the region by oil activities.

It is evident from reviewed literature that documents abound on the health, economic as well as environmental effects of crude oil production. However, little is published regarding the social dimension, if any, of crude oil production in Nigeria. This paper therefore focuses on the relationship between crude oil production and social lives of oil-bearing communities.

\section{METHODS}

Five of the thirteen communities in Egbema, Imo State, were studied, they are; Mmahu, Obiakpu, 
Opuoma, Abacheke and Etekwuru. These were selected because they are the major oil producing communities in Egbema, Imo State. This study adopted questionnaire survey as well as oral interview with heads of households in selected communities. One hundred and fifty (150) copies of well-structured questionnaire were distributed to respondents in the study area. 30 copies of questionnaire were distributed to each of the studied communities. Of this number, one hundred and forty one (141) were correctly filled and returned, this accounts for 94 percent of respondents.

Ten oral interviews, that is, two for each studied community were conducted. This was done to ascertain types of social/cultural activities prevalent in the area. These oral interviews were conducted with the heads of households either male or female. Some information not contained in the questionnaire were also derived from these exercises. Data obtained from these interviews alongside analysis of questionnaire data and testing of hypothesis formed the basis for the conclusions and recommendations of this paper.

\section{RESULTS AND DISCUSSION}

Social activities identified in the community include; peer group meetings, naming ceremonies, traditional marriage ceremonies among others. Identified crude oil production activities going on in the community include crude oil prospecting, oil/gas extraction and transportation, gas flaring, geologic surveys, and acquisition of lands by oil companies. Of all the crude oil production activities going on in the area, crude oil extraction had the highest frequency of 82 respondents or 58.2 percent as shown in Table 1.

Table 1. Crude oil production activities in the study area

\begin{tabular}{|c|c|c|}
\hline $\begin{array}{l}\text { Crude oil } \\
\text { production } \\
\text { activities }\end{array}$ & Frequency & Percentage \\
\hline $\begin{array}{l}\text { Crude oil } \\
\text { prospecting }\end{array}$ & 6 & 4.2 \\
\hline $\begin{array}{l}\text { Crude oil } \\
\text { extraction }\end{array}$ & 82 & 58.2 \\
\hline $\begin{array}{l}\text { Geologic } \\
\text { surveys }\end{array}$ & 12 & 8.5 \\
\hline $\begin{array}{l}\text { Land } \\
\text { acquisition }\end{array}$ & 19 & 13.5 \\
\hline Gas flaring & 20 & 15.6 \\
\hline Total & 141 & 100 \\
\hline
\end{tabular}

The information in Table 1 further shows that crude oil prospecting had the lowest frequency of 6 or 4.2 percent. Information on identified social effects of crude oil production is illustrated in Table 2.

\section{Table 2. Identified social effects of crude oil production activities}

\begin{tabular}{lll}
\hline $\begin{array}{l}\text { Identified } \\
\text { social effect }\end{array}$ & Frequency & Percentage \\
\hline $\begin{array}{l}\text { Inability to } \\
\text { meet with } \\
\text { friends }\end{array}$ & 44 & 31.2 \\
$\begin{array}{l}\text { Traditional } \\
\text { marriages }\end{array}$ & 14 & 9.9 \\
$\begin{array}{l}\text { Neglect of } \\
\text { cultural }\end{array}$ & 14 & 9.9 \\
$\begin{array}{l}\text { activities } \\
\text { Naming }\end{array}$ & 22 & 15.6 \\
$\begin{array}{l}\text { ceremonies } \\
\text { Burial } \\
\text { ceremonies }\end{array}$ & 24 & 17.0 \\
$\begin{array}{l}\text { No identified } \\
\text { effect }\end{array}$ & 23 & 16.3 \\
Total & 141 & 100 \\
\hline \multicolumn{2}{c}{ Source: authors research 2017 }
\end{tabular}

The data in Table 2 show that majority of the respondents reported that crude oil production activities have affected their abilities to meet with friends and peers, a total of 44 or 31.2 percent of respondents made this observation. On the other hand, 14 respondents or 9.9 percent of sampled population agree that crude oil production in their communities has affected their traditional marriages and led to neglect of cultural practices.

\section{RECOMMENDATIONS}

Many authors have documented environmental, economic and health effects of crude oil production activities. This study has shown that social lives of people in oil producing communities are not significantly affected by crude oil production. Issues of restiveness were however reported in the study area. A number of reasons were given for this problem, though, assessment of security effects of crude oil production is beyond the scope of this study. Security issues such as restiveness gradually have a way of robbing an individual of their social life thereby making them more hostile to friends and family. This study therefore recommends further research on security effects of crude oil production in Nigeria. 


\section{CONCLUSIONS}

This study set out to fill the gap existing in published literature as regards social effects of crude oil production in Nigeria. Analysis of data and results show that social activities such as traditional marriages, meetings with peers, naming ceremonies, cultural activities and funerals in the community studied have not been significantly affected by crude oil production activities such as gas flaring, crude oil extraction as well as geologic surveys. Based on this, it is now safe to state that crude oil extraction activities do not significantly affect social lives of people in the oil producing communities of Nigeria. The importance of this research is that despite the environmental degradation in the oil producing communities, the economic stagnation occasioned by decline in economic activities (such as fishing), loss of agricultural products as observed by previous authors $[1,14]$, social activities are still intact. These social activities help the people live and not merely exist in the face of challenges they face from effects of crude oil productions activities in their environment. It is equally possible that these social gatherings present the communities a common ground to discuss some of the environmental, economic and health implications of crude oil production activities with a view to channelling their challenges to the appropriate authorities. One could therefore conclude based on the result of this research that the psychological effects of crude oil production activities as observed by [13] could have been worse were it not for these successful social activities. One could imagine the fate of oil bearing communities if both economic and agricultural activities were down, people's health affected as a product of crude oil production activities, and their social lives significantly affected as well, all due to crude oil production. Such communities would not be liveable and probably deserted. The next logical step would be to assess security effects of crude oil production in the oil producing communities. This will add to a holistic wealth of knowledge on effects of crude oil production on the physical environment, economic activities, social lives and security of lives and property of oil producing communities.

\section{COMPETING INTERESTS}

Authors have declared that no competing interests exist.

\section{REFERENCES}

1. Ebegbulem J, Ekpe D, Adejumo TO. Oil exploration and poverty in the Niger delta region of Nigeria: A critical analysis. International Journal of Business and Social Science. 2013;4(3):279-287.

2. Bascetin A. A decision support system using analytical hierarchy process (AHP) for the optimal environmental reclamation of an open-pit mine. Environmental Geology. 2007;52(4):663-672.

3. Ordinioha B, Brisibe $S$. The human health implications of crude oil spills in the Niger delta, Nigeria: An interpretation of published studies. Nigerian Medical Journal. 2013;54(1):10.

4. Elum ZA, Mopipi K, Henri-Ukoha A. Oil exploitation and its socioeconomic effects on the Niger Delta region of Nigeria. Environmental Science and Pollution Research. 2016;23(13):12880-12889.

5. Baghebo M, Atima TO. The impact of petroleum on economic growth in Nigeria. Global Business and Economics Research Journal. 2013;2(5):102-115.

6. Ahmadu J, Egbodion J. Effect of oil spillage on cassava production in Niger Delta region of Nigeria. American Journal of Experimental Agriculture. 2013;3(4): 914-926.

7. Budnuka AC, Clinton A, Agi-Ottoh C. The effect of unplanned exploitation of environmental resources: The Nigeria's experience. Journal of Environment Pollution and Human Health. 2015;3(2):3945.

8. Francis IA. Correlation between the bearing capacity of crude oil contaminated soil of Mgbede and the percentage contamination. Journal of Civil Engineering and Architecture. 2013;7(12):1595.

9. Azaiki SS. Oil, gas and life in Nigeria. YBooks; 2007.

10. Ajide OM, Isaac OO. An assessment of the physical impact of oil spillage using GIS and remote sensing technologies: Empirical evidence from Jesse town, Delta state, Nigeria. British Journal of Arts and Social Sciences. 2013;12:235-252.

11. Ite AE, Ibok UJ, Ite MU, Petters SW. Petroleum exploration and production: Past and present environmental issues in the Nigeria's Niger Delta. American Journal of Environmental Protection. 2013;1(4):78-90. 
12. Oghenejoboh $\mathrm{KM}$, Babatunde $\mathrm{AA}$, Nwaukwa CT. Effects of air pollution arising from associated gas flaring on the economic life of the people of oil producing communities in Nigeria. I Control Pollution. 2015;2007.

13. Nriagu J, Udofia EA, Ekong I, Ebuk G. Health risks associated with oil pollution in the Niger Delta, Nigeria. International Journal of Environmental Research and Public Health. 2016;13(3):346.

14. Okonkwo CNP, Kumar L, Taylor S. The Niger Delta wetland ecosystem: What threatens it and why should we protect it? African Journal of Environmental Science and Technology. 2015;9(5):451-463.

(c) 2017 Osumgborogwu et al.; This is an Open Access article distributed under the terms of the Creative Commons Attribution License (http://creativecommons.org/licenses/by/4.0), which permits unrestricted use, distribution, and reproduction in any medium, provided the original work is properly cited.

Peer-review history:

The peer review history for this paper can be accessed here:

http://sciencedomain.org/review-history/19223 